\title{
Optimization of removal of calcium ions forming during synthesis of boric acid from ulexite ore by using ion exchange resin
}

\author{
Tuba Hatice Doğan1*, Ahmet Yartaşı \\ ${ }^{1}$ Atatürk University, Department of Chemical Engineering, 25240, Erzurum, Turkey; ORCID ID, orcd.org/0000-0001-8369-9416 \\ ${ }^{2}$ Çankırı Karatekin University, Department of Chemistry, 18100, Çankırı, Turkey. ORCID ID, orcd.org/0000-0003-0469-4575
}

\section{ARTICLE INFO}

\section{Article history:}

Received 03 July 2017

Received in revised form 10 May 2018

Accepted 16 May 2018

Available online 05 July 2018

Research Article

DOI: $10.30728 /$ boron.325756

\section{Keywords:}

Ulexite,

Boric Acid,

Calcium removal,

lon exchange resin,

Taguchi optimization

\begin{abstract}
Ulexite $\left(\mathrm{Na}_{2} \mathrm{O} \cdot 2 \mathrm{CaO} \cdot 5 \mathrm{~B}_{2} \mathrm{O}_{3} \cdot 16 \mathrm{H}_{2} \mathrm{O}\right)$ is one of the most important raw materials for boric acid, synthesized by dissolving the ore in an acid solution. Since ulexite ore was dissolved in a phosphoric acid solution, the final solution included boric acid $\left(\mathrm{H}_{3} \mathrm{BO}_{3}\right)$, sodium dihydrogen phosphate $\left[\mathrm{NaH}_{2} \mathrm{PO}_{4}\right]$, and calcium dihydrogen phosphate $\left[\mathrm{Ca}\left(\mathrm{H}_{2} \mathrm{PO}_{4}\right)_{2}\right]$. The presence of several ions in the solution causes separation problems for boric acid. This study includes a special separation step to increase the purity of the boric acid that is synthesized from the dissolution of ulexite ore in phosphoric acid. For this purpose, calcium ions in the final solution were removed using Dowex HCR-S cationic ion exchange resin. Additionally, the Taguchi optimization method was employed to monitor the removal of calcium ions. The design of experiments included an orthogonal array technique in $\mathrm{L}_{9}$ array for three parameters with three different values; reaction temperature $\left(12^{\circ} \mathrm{C}, 25\right.$ $\left.{ }^{\circ} \mathrm{C}, 40{ }^{\circ} \mathrm{C}\right)$, stirring rate $(250 \mathrm{rpm}, 300 \mathrm{rpm}, 350 \mathrm{rpm})$, and the amount of resin (10\% wt., $30 \%$ wt., $50 \%$ wt.). The results of the calculations revealed that the optimum values of temperature, stirring rate, and amount of resin are $12{ }^{\circ} \mathrm{C}, 350$ rpm, and $50 \%$ wt., respectively. The amount of calcium removed under optimum conditions was found as $79.49 \%$.
\end{abstract}

\section{Introduction}

Turkey contains a major portion of the world's total boron reserves. Turkey's commercially recoverable boron reserves comprise colemanite $\left(\mathrm{Ca}_{2} \mathrm{~B}_{6} \mathrm{O}_{11} \cdot 5 \mathrm{H}_{2} \mathrm{O}\right)$, ulexite $\left(\mathrm{NaCaB}_{5} \mathrm{O}_{9} \cdot 8 \mathrm{H}_{2} \mathrm{O}\right)$ and tincal $\left(\mathrm{Na}_{2} \mathrm{~B}_{4} \mathrm{O}_{7} \cdot 10 \mathrm{H}_{2} \mathrm{O}\right)$ and various products are produced from these boron compounds [1]. Boron and its products are used widely in industry. Some of the application areas for boron compounds are the defense industry, glass industry, for glass fibers, ceramic industry, industrial cleaning and whitening, as flame-retardant materials, in agriculture, metallurgy, nuclear applications, energy storage, waste removal, fuel and health, etc. [2, 3].

Boric acid is the most important product in the boron industry. It is used as the main precursor for the production of many boron additive materials. Therefore, the purity of boric acid is very important for the boron market and user, and innovative research into the production of pure boric acid and cost effective production methods has generally received great interest.

In Turkey, boric acid is produced by the reaction of sulfuric acid with colemanite. However, many problems are encountered during filtration of gypsum $\left(\mathrm{CaSO}_{4} \cdot 2 \mathrm{H}_{2} \mathrm{O}\right)$ which forms as a by-product of this reaction. The most significant problems are that gypsum forms as a result of the reaction, mixes with clay minerals from ore and has no economic value. In addition to this, it may cause environmental problems as it still includes resoluble boric acid within solid waste and causes vast areas to be used for solid waste storage. Difficulties experienced during drainage of gypsum and problems such as sulfuric acid causing excessive corrosion increase the production costs of this process $[4,5,6]$. Therefore, various alternative studies have been carried out in order to decrease the cost of boric acid produced with conventional methods, to generate environment-friendly new technologies and to contribute to scientific technology. In studies, boric acid has been produced by dissolving boron ores in various solvents. Boric acid was produced by dissolving native borates in $\mathrm{H}_{3} \mathrm{PO}_{4}$ solutions [7], colemanite in $\mathrm{H}_{3} \mathrm{PO}_{4}$ solutions [8], Kestelek's colemanite containing clay minerals in water saturated with sulfur dioxide [9], ulexite ore in phosphoric acid [10] and colemanite ore in methanol [11].

Another alternative method for production of boric acid is dissolving ulexite ore within a phosphoric acid solution. As is known, ulexite ore is one of the most common boron ores in Turkey. Therefore, its use for boric acid production is quite convenient. Also, when 
phosphoric acid is used as solvent in this process, other valuable by-products are also produced apart from boric acid, such as sodium and calcium phosphates $[7,10]$. Therefore, when phosphoric acid is used these valuable by-products can be produced and also difficulties experienced during disposal of gypsum, which forms as a by-product in the traditional method, and problems encountered due to the corrosive effect of sulfuric acid are resolved. Therefore, when all the mentioned advantages are considered, this process may be a different alternative to produce boric acid.

Some researchers have been concerned with the optimization of boric acid production by dissolution of boron minerals using the Taguchi method. The optimization of dissolution of ulexite in $\mathrm{NH}_{4} \mathrm{Cl}$ solutions [12], colemanite in water saturated with $\mathrm{CO}_{2}$ and $\mathrm{SO}_{2}$ gases [13] and ulexite in phosphate acid solutions [14] was investigated and the optimum conditions for the process was determined in all studies.

Taguchi is an optimization method commonly used in engineering applications to optimize the process. It is a simple and effective method used to provide maximum performance with minimum cost [15]. The Taguchi method is based on the principle of running the experiment as few times as possible to keep costs at the lowest level. An orthogonal array is used to reduce the number of experiments in this method. The difference between the Taguchi method and other statistical methods is that it examines the parameters affecting an experiment in two groups as controllable and uncontrollable. The results obtained during the experimental work may also be obtained in a factory environment using this method [16].

As is known, various by-products occur in all dissolution studies performed to synthesize boric acid from boron ores. Although separation of boric acid from these by-products is very important, not many studies on this subject are found in the literature. Therefore, the aims of this study are to investigate the optimization of a stage to help separate boric acid from a product solution we obtained from a previously completed study. In our previous study, ulexite ore was dissolved in phosphoric acid solution to produce boric acid and the formation of sodium and calcium dihydrogen phosphates was observed as by-products [10].

In this study, calcium ions in the product solution from the previous study were removed using Dowex HCR-S cationic ion exchange resin. In this manner, the purity of the boric acid synthesized from the dissolution of ulexite ore in phosphoric acid was increased. Additionally, the Taguchi optimization method was employed to monitor the removal of calcium ions.

\section{Materials and methods}

\subsection{Materials}

The ulexite ore used in the study was provided from the region of Bigadiç, Balıkesir, Turkey. It was ground and sieved by ASTM standard sieves. In the experiments, ulexite ore with grain size of $-212+150 \mu m$ diameter - which was determined to have high boric acid transformation in pre-experiments- was used. The chemical analysis of the ore was performed by volumetric and gravimetric methods and its purity was found to be about $93 \%$ on the basis of $\mathrm{B}_{2} \mathrm{O}_{3}$ content (Table 1).

Table 1. The chemical analysis of ulexite ore with diameter $-212+150$ $\mu \mathrm{m}$.

\begin{tabular}{cc}
\hline Component & \% Composition \\
\hline $\mathrm{B}_{2} \mathrm{O}_{3}$ & 40.15 \\
$\mathrm{H}_{2} \mathrm{O}$ & 33.22 \\
$\mathrm{CaO}$ & 13.89 \\
$\mathrm{Na}_{2} \mathrm{O}$ & 6.82 \\
$\mathrm{MgO}_{\mathrm{SiO}}$ & 2.69 \\
Others & 1.12 \\
\hline
\end{tabular}

X-ray diffraction analysis was performed to determine the mineralogical structure of the original ulexite sample using a Rigaku D/MAX-2200 diffractometer. Phase identification was carried out using the available data from an inorganic crystal structure database (ICSD). The characteristic peaks of ulexite ore were observed. The $x$-ray diffractogram of ulexite ore is given in Figure 1.

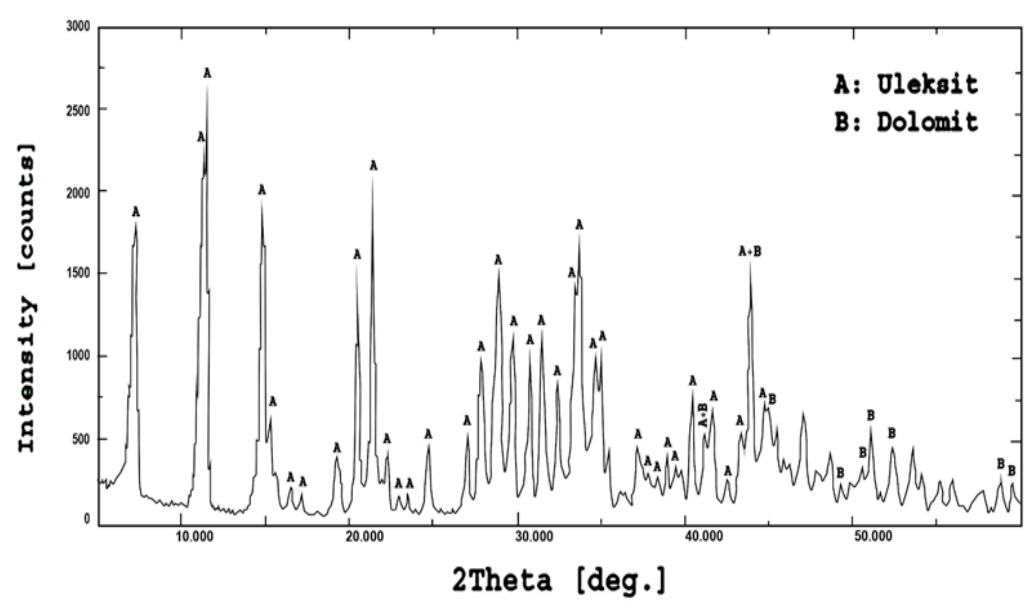

Figure 1. X-ray diffractogram of ulexite ore. 
Phosphoric acid was obtained from Merck and was $85 \%$ by weight. The resin used in the study was synthetic Dowex-HCR S/S in sodium form provided by Fluka Co. Some of the properties of this resin are given in Table 2.

\subsection{Dissolution experiments}

A $250 \mathrm{~mL}$ jacketed glass reactor was used for dissolution experiments. A constant temperature circulator and a reflux condenser were attached to the reactor. The reactor contents were stirred with a mechanical stirrer. After putting $0.1 \mathrm{~L}$ phosphoric acid solution $(0.7$ $\mathrm{M})$ into the reactor, the reactor was heated to $60^{\circ} \mathrm{C}$. $15 \mathrm{~g}$ ulexite ore was added to the reactor while the stirring (200rpm) was continued. After 30 minutes, the reactor contents were filtered quickly.

The reaction conditions we use here are the optimum dissolution conditions we have determined in our previous work [13]. The product solution obtained after dissolution was transferred to another reactor for ion exchange experiments. The experimental setup used for the dissolution experiments is given in Figure 2.

\subsection{Ion-exchange experiments}

The experimental setup (Figure 2.) described above was used for the ion exchange experiments. $0.1 \mathrm{~L}$ product solution was put into the reactor and the contents were heated to the desired temperature. After reaching the desired temperature, a certain amount of resin was placed into the reactor. After finishing the reaction, the reactor contents were filtered and the amount of calcium in the obtained solution was analyzed [17]. The preliminary experiments showed that the maximum calcium ion removal was achieved in five minutes (Figure 3).

As shown in Figure 3, the amount of calcium removal did not change after the fifth minute. Therefore, five minutes was selected as the experimental period.

\section{Results and discussion}

The product solution contained boric acid $\left(\mathrm{H}_{3} \mathrm{BO}_{3}\right)$, sodium dihydrogen phosphate $\left[\mathrm{NaH}_{2} \mathrm{PO}_{4}\right]$, and calcium dihydrogen phosphate $\left[\mathrm{Ca}\left(\mathrm{H}_{2} \mathrm{PO}_{4}\right)_{2}\right]$ after ulexite ore was dissolved in phosphoric acid [10]. This product solution was treated with an ion exchange resin to remove calcium ions in solution. Experimental parameters and their values were determined in pre-trials and are given in Table 3.

The experimental plan, $L_{9}\left(3^{3}\right)$, three parameters and three levels, was determined by using the orthogonal array (OA) technique and is given in Table 4.

Each experiment was repeated twice under the same conditions at different times. In this way the effects of

Table 2. Properties of Dowex HCR-S resin.

\begin{tabular}{ll}
\hline Parameters & Value \\
\hline Type & Acid cation \\
Total exchange capacity, min. & $1.9 \mathrm{eq} / \mathrm{mL}$ \\
Particle size & $300-1200 \mu \mathrm{m}$ \\
$\mathrm{pH}$ & $0-14$ \\
Max. oper. temperature & $120^{\circ} \mathrm{C}$ \\
lonic form & $\mathrm{Na}^{+}$ \\
Particle density & $1.3 \mathrm{~g} / \mathrm{mL}$ \\
Physical form & Uniform particle size spherical beads \\
\hline
\end{tabular}

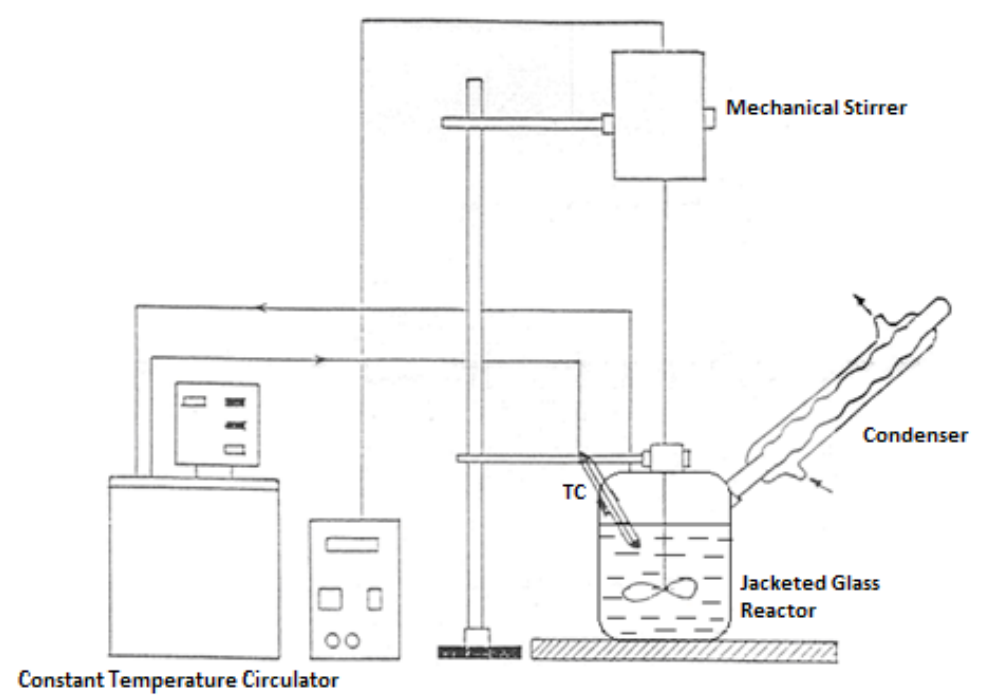

Figure 2. The experimental setup for ion-exchange experiments. 


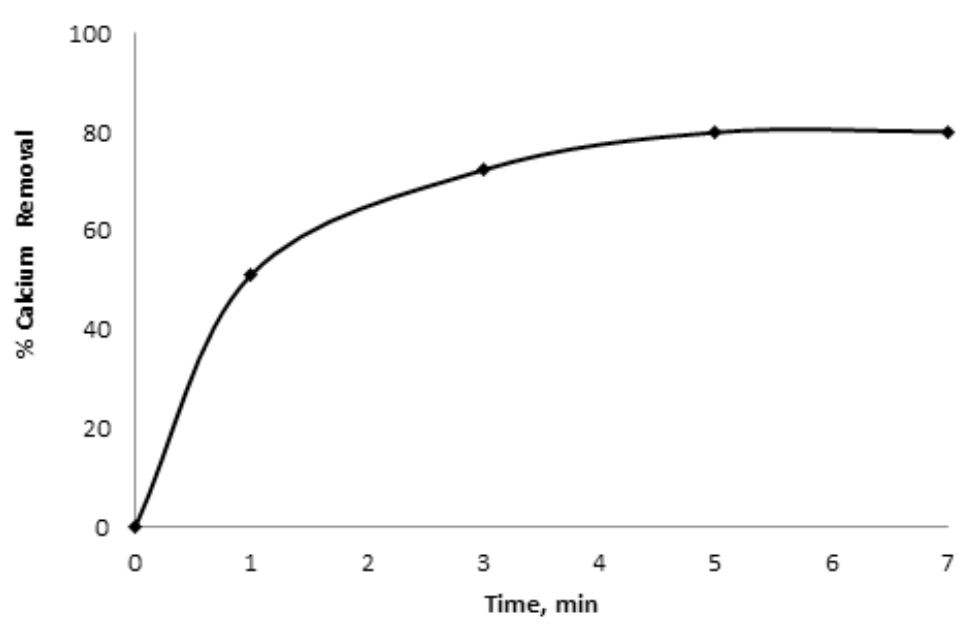

Figure 3. The variation of calcium removal with time during pre-experiments.

Table 3. Parameters and their values corresponding to the levels to be studied in experiments.

\begin{tabular}{|c|c|c|c|c|}
\hline \multirow{2}{*}{\multicolumn{2}{|c|}{ Parameters }} & \multicolumn{3}{|c|}{ Levels } \\
\hline & & 1 & 2 & 3 \\
\hline$A$ & $\begin{array}{l}\text { Reaction temperature } \\
\left({ }^{\circ} \mathrm{C}\right)\end{array}$ & 12 & 25 & 40 \\
\hline B & $\begin{array}{c}\text { Stirring speed } \\
(\mathrm{rpm})\end{array}$ & 250 & 300 & 350 \\
\hline $\mathrm{C}$ & $\begin{array}{l}\text { Resin amount } \\
\text { (wt.\%) }\end{array}$ & 10 & 30 & 50 \\
\hline
\end{tabular}

Table 4. $\mathrm{L}_{9}\left(3^{3}\right)$ experimental plan table.

\begin{tabular}{cccc}
\hline \multirow{2}{*}{$\begin{array}{c}\text { Experiment } \\
\text { number }\end{array}$} & \multicolumn{3}{c}{ Parameters and their levels } \\
\cline { 2 - 4 } & A & B & C \\
\hline 1 & 1 & 1 & 1 \\
2 & 1 & 2 & 2 \\
3 & 1 & 3 & 3 \\
4 & 2 & 1 & 2 \\
5 & 2 & 2 & 3 \\
6 & 2 & 3 & 1 \\
7 & 3 & 1 & 3 \\
8 & 3 & 2 & 1 \\
9 & 3 & 3 & 2 \\
\hline
\end{tabular}

uncontrollable factors negatively affecting the results were determined.

According to Taguchi, as the optimization criterion the $\mathrm{S} / \mathrm{N}$ ratio should be used to identify the quality characteristics. This ratio can be divided into three categories. They are the larger the better, the smaller the better and the nominal the better [18]. The larger the better performance characteristics were used to obtain optimum calcium removal performance. The $S / N$ values for the average effects are calculated from Eq. (1).

$S / N=-10 \log _{10}\left(\frac{1}{n} \sum_{i=1}^{n} \frac{1}{Y_{i}^{2}}\right)$

where $S / N$ is the performance statistics, $n$ the number of repetitions done for an experimental combination, and $Y_{i}$ performance value of ith experiment.

If experimental results are in percentage (\%), omega transformation of percentage values should be applied using Eq. (2).

$\Omega(\mathrm{db})=-\log \left(\frac{1}{P}-1\right)$

where $\Omega(d b)$ is the decibel value of percentage value subject to omega transformation and $P$ percentage of the product obtained experimentally.

The values that make $\mathrm{S} / \mathrm{N}$ maximum are optimum. The experiment corresponding to optimum conditions may not have been performed during the experimental work using the Taguchi method. In this case, the performance value corresponding to the optimum conditions can be estimated from Eq. (3) [19].

$Y_{i}=\mu+X_{i}+e_{i}$

where $\mu$ is the overall mean of performance value at the optimum conditions, $X_{i}$ the fixed effect of the parameter level combination used in ith experiment, and $e_{i}$ the random error in ith experiment.

Equation 3 is a point estimate calculated by using experimental data. Therefore, the confidence interval (CI) must be calculated to decide whether this value is meaningful or not. The confidence interval can be calculated from Eq. (4) at a selected error level.

$C I=\mu \pm \sqrt{\frac{F\left(1, n_{2}\right) V_{e}}{N_{e}}}$

where $F\left(1, n_{2}\right)$ is the $F$ value from the $F$ table in any statistical book at the required confidence level and at degrees of freedom (DOF) 1 and error DOF $n_{2}$; Ve is the variance of error term (from ANOVA); and $\mathrm{Ne}$ is the effective number of replications

$N_{e}=\frac{\text { Total number of results }(\text { or number of } S / \text { Nratios })}{\text { DOF of mean }(=1 \text { always })+D O F \text { of all factors included in the estimate of the mean }}$ 
Table 5. The experimental results and $\mathrm{S} / \mathrm{N}$ values calculated for these results.

\begin{tabular}{|c|c|c|c|c|c|c|}
\hline \multirow[b]{2}{*}{$\begin{array}{l}\text { Experiment } \\
\text { number }\end{array}$} & \multicolumn{3}{|c|}{ Parameters and their levels } & \multicolumn{2}{|c|}{$\%$ Calcium removal } & \multirow[b]{2}{*}{$\begin{array}{c}\text { Performance } \\
\text { statistics (S/N) }\end{array}$} \\
\hline & $\begin{array}{l}\text { Reaction } \\
\text { Temp. } \\
\left({ }^{\circ} \mathrm{C}\right)\end{array}$ & $\begin{array}{l}\text { Stirring } \\
\text { speed } \\
\text { (rpm) }\end{array}$ & $\begin{array}{c}\text { Resin } \\
\text { amount } \\
\text { (wt.\%) }\end{array}$ & Experiment I & Experiment II & \\
\hline 1 & 12 & 250 & 10 & 25.86 & 30.01 & 28.8510 \\
\hline 2 & 12 & 300 & 30 & 69.20 & 67.70 & 36.7059 \\
\hline 3 & 12 & 350 & 50 & 80.01 & 78.97 & 38.0057 \\
\hline 4 & 25 & 250 & 30 & 62.50 & 63.10 & 35.9589 \\
\hline 5 & 25 & 300 & 50 & 63.00 & 62.50 & 35.9521 \\
\hline 6 & 25 & 350 & 10 & 25.01 & 25.01 & 27.9623 \\
\hline 7 & 40 & 250 & 50 & 57.14 & 58.03 & 35.2054 \\
\hline 8 & 40 & 300 & 10 & 25.00 & 22.98 & 27.5775 \\
\hline \multirow[t]{2}{*}{9} & 40 & 350 & 30 & 62.50 & 60.67 & 35.7866 \\
\hline & & & & & Average & 33.5562 \\
\hline
\end{tabular}

\subsection{Performance statistics (S/N)}

Ion exchange experiments were carried out according to the experimental plan in Table 4. The obtained experimental results and the $\mathrm{S} / \mathrm{N}$ values calculated for these results are given in Table 5.

$\mathrm{S} / \mathrm{N}$ values were calculated using Eq. 1. The first $\mathrm{S} / \mathrm{N}$ value in Table 5 was calculated as follows;

$$
\begin{aligned}
& S / N=-10 \log _{10} \frac{1}{2}\left(\frac{1}{25.86^{2}}+\frac{1}{30.01^{2}}\right) \\
& S / N=28.8510
\end{aligned}
$$

The other $\mathrm{S} / \mathrm{N}$ values in Table 5 were calculated in the same way. The average effects (AE) of calcium removal were calculated using these results. The average effects of each level for the various parameters are given Table 6 and shown in Figure 4.

Table 6. The average effects of calcium removal from product solutions.

\begin{tabular}{cccc}
\hline $\begin{array}{c}\text { Level } \\
\text { number }\end{array}$ & Parameter A & Parameter B & Parameter C \\
\hline $1^{\text {st }}$ Level & 34.5209 & 33.3384 & 28.1303 \\
$2^{\text {nd }}$ Level & 33.2911 & 33.4118 & 36.1505 \\
$3^{\text {rd }}$ Level & 32.8565 & 33.9182 & 36.3877 \\
\hline
\end{tabular}

Level 1 of A parameter in Table 6 was calculated as follows;

$A E=(28.8510+36.7059+38.0057) / 3$

$\mathrm{AE}=34.5209$

The other values in Table 6 were calculated in the same way.

Figure 4 indicates the change in performance characteristics with process parameters. For example, Figure 4C indicates the change in $S / N$ ratios with the resin amount. Level 1 of $\mathrm{C}$ parameter is $10 \%$. The highest $\mathrm{S} / \mathrm{N}$ value on each graph is the optimum value for that parameter. Therefore, optimum calcium removal conditions for this process were found to be $\mathrm{A} 1\left(12^{\circ} \mathrm{C}\right), \mathrm{B} 3$ (350 rpm) and C3 (50 wt.\%). Similarly, when Table 5

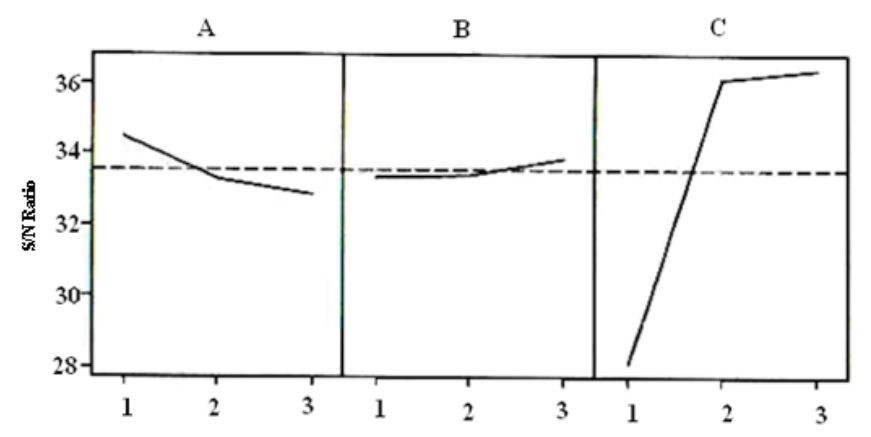

Figure 4. The mean effects plot for $\mathrm{S} / \mathrm{N}$ ratios.

is analyzed, the highest $\mathrm{S} / \mathrm{N}$ value is 38.0057 and this value is the optimum value. Parameter values corresponding to this value are respectively $12^{\circ} \mathrm{C}$ temperature, $350 \mathrm{rpm}$ mixing speed and $50 \%$ resin amount.

The solution obtained as a result of ion exchange experiments carried out under optimum conditions was analyzed. These analysis results and analysis results for the solution before ion exchange are given in Table 7.

Table 7. Chemical analysis results in solution before and after the ion exchange.

\begin{tabular}{ccc}
\hline & $\begin{array}{c}\text { Before the ion } \\
\text { exchange (wt.\%) }\end{array}$ & $\begin{array}{c}\text { After the ion } \\
\text { exchange (wt.\%) }\end{array}$ \\
\hline $\mathrm{Ca}$ & 9.68 & 1.94 \\
$\mathrm{Na}$ & 4.97 & 13.87 \\
\hline
\end{tabular}

As seen in Table 7, calcium ions decreased from $9.68 \%$ to $1.94 \%$, while sodium ions increased from $4.97 \%$ to $13.87 \%$. According to this, nearly $80 \%$ of calcium ions in product solution were removed after ion exchange under optimum conditions. Calcium ions in the product solution were replaced by sodium ions using the ion exchange resin. There were already sodium ions in the product solution. With the ion exchange reaction, only the sodium ion concentration in the solution increased. Thus, variation in the product solution was reduced and the purity of the boric acid was increased.

Various methods such as chemical precipitation and membrane filtration can be used for removal of calcium ions. However, the ion exchange process has 
various advantages compared to these methods. These advantages are that the cost is lower than membrane filtration, there is no new pollution that would pass into solution during chemical precipitation, high removal speed, simple device and easy operation. Moreover, innovative research that contributes to literature was carried out by using ion exchanger for such a separation process. Furthermore, the resin can be regenerated with salt solution and does not require any chemical treatment. Therefore, using ion exchange resin for the removal of calcium ions from the product solution provides many important advantages.

\subsection{Analysis of variance}

An analysis of variance (ANOVA) was carried out to identify the effective parameters and their confidence intervals for calcium removal using ion exchange resin from solutions obtained by dissolution of ulexite in phosphate acid solution. The ANOVA is a standard table containing the values as sum of squares, degrees of freedom, F, etc. The optimum process parameters can be predicted using the ANOVA and the S/N values [20]. The ANOVA table for the calcium removal values in the experiments was created (see Table 8).

The $F$ value in Table 8 is used to determine the effective parameters. F-value of each parameter is the ratio of the mean of the squared deviations to the mean of squared error. The larger the F-value, the greater the effect. Therefore, the amount of resin is the most effective parameter for this process.

When Table 8 is investigated it appears that the most effective parameter on the process is the amount of resin with $94.59 \%$ contribution. At the same temperature $\left(12{ }^{\circ} \mathrm{C}\right)$, increasing the resin amount from $10 \%$ to $50 \%$ increases calcium removal from nearly $30 \%$ to $80 \%$ (Table 5). It is readily understood that the number of available adsorption sites increases by increasing the resin amount and therefore, variation in resin amount results in an increase in removal efficiency. Additionally according to Table 8, while there was no effect on the ion exchange process from stirring speed, temperature did affect this process though not by much. When the experimental results in Table 5 are investigated, in experiments with the same amount of resin $(50 \%)$ used as temperature increased the calcium removal decreased. A decrease in the removal efficiency of calcium ions with the rise in temperature was due to the increasing tendency to desorb from the interface into the solution. This result also indicates that the adsorption process of calcium ions onto resin is exothermic. When the same resin amount was used (e.g., 10\%), increasing the stirring speed from $250 \mathrm{rpm}$ to $350 \mathrm{rpm}$ did not cause a significant change in calcium removal amount (Table 5). This shows that there was no resistance to mass transfer at any existing solid-liquid and liquid-liquid interfaces and the ion exchange reaction at all speeds is generally not controlled by external diffusion.

The calculations in the ANOVA table were made as follows:

Step 1 Total of all experimental results $(\mathrm{T})$ :

$\mathrm{T}=28.8510+36.7059+38.0057+\ldots \ldots .+35.7866=$ 302.01

Step 2 Correction factor (CF):

$C F=\frac{T^{2}}{n}=\frac{302.01^{2}}{9}=10134.45$

where $n$ is the total number of experiments.

Step 3 Total sum of squares $\left(\mathrm{S}_{\mathrm{T}}\right)$ :

$S_{T}=\sum_{i=1}^{9} Y_{i}^{2}-C F$

$S_{T}=\left(28.8510^{2}+36.7059^{2}+\ldots .+35.7866^{2}\right)-10134.45$

$S_{T}=137.792$

Step 4 Parameter sum of squares:

$S_{A}=\frac{A_{1}^{2}}{N_{A 1}}+\frac{A_{2}^{2}}{N_{A 2}}+\frac{A_{3}^{2}}{N_{A 3}}-C F$

$A_{1}=A_{11}+A_{12}+A_{13}=28.8510+36.7059+38.0057=103.56$

$A_{2}=A_{21}+A_{22}+A_{23}=35.9589+35.9521+27.9623=99.87$

$A_{3}=A_{31}+A_{32}+A_{33}=35.2054+27.5775+35.7866=98.57$

$\mathrm{N}_{\mathrm{A} 1}=3$ (total number of experiments in which parameter $A_{1}$ is present)

Table 8. Results of the analysis of variance for the calcium removal values in the experiments.

\begin{tabular}{cccccccc}
\hline & Parameters & $\begin{array}{c}\text { Sum of } \\
\text { Squares } \\
\text { (SS) }\end{array}$ & $\begin{array}{c}\text { Degrees } \\
\text { of } \\
\text { freedom } \\
\text { (DOF) }\end{array}$ & $\begin{array}{c}\text { Mean of } \\
\text { Squares } \\
\text { (Variance) }\end{array}$ & $\boldsymbol{F}$ & $\begin{array}{c}\text { Pure } \\
\text { SS }\end{array}$ & $\begin{array}{c}\text { Percent of } \\
\text { the } \\
\text { contribution } \\
\text { (\%) }\end{array}$ \\
\hline $\mathrm{A}$ & $\begin{array}{c}\text { Reaction } \\
\text { temperature }\left({ }^{\circ} \mathrm{C}\right)\end{array}$ & 3.795 & 2 & 1.90 & 2.47 & 2.255 & 1.60 \\
$\mathrm{~B}$ & $\begin{array}{c}\text { Stirring speed } \\
(\mathrm{rpm})\end{array}$ & 0.590 & 2 & 0.30 & 0.39 & 0 & 0 \\
$\mathrm{C}$ & $\begin{array}{c}\text { Resin amount } \\
(\text { wt.\%) } \\
\text { Error }\end{array}$ & 131.877 & 2 & 65.94 & 85.64 & 130.337 & 94.59 \\
& 1.53 & 2 & 0.77 & & & 3.81 \\
\hline
\end{tabular}


$\mathrm{N}_{\mathrm{A} 2}=3$ (total number of experiments in which parameter $\mathrm{A}_{2}$ is present)

$\mathrm{N}_{\mathrm{A} 3}=3$ (total number of experiments in which parameter $\mathrm{A}_{3}$ is present)

$S_{A}=\frac{1}{3} \sum_{i}^{3} A_{i}^{2}-C F$

$S_{A}=\frac{103.56^{2}}{3}+\frac{99.87^{2}}{3}+\frac{98.57^{2}}{3}-10134.45$

$S_{A}=3.795$

$S_{B}$ and $S_{C}$ were calculated in the same way.

Step 5 Error sum of squares:

$S_{e}=S_{T}-\left(S_{A}+S_{B}+S_{C}\right)$

$S_{e}=137.792-(3.795+0.590+131.877)$

$S_{e}=1.53$

Step 6 Total, parameter and error degrees of freedom (DOF)

DOF total $=$ Number of experimental runs minus 1

$f_{T}=9-1=8$

DOF $A$ parameter $=$ level number of parameter $A$ minus 1

$f_{A}=n-1=3-1=2$ and so on.

DOF error $=$ DOF total $-\sum_{i=1}^{n}(D O F)_{i}$

$f_{e}=f_{T}-\sum_{i=1}^{3} f_{i}$

$f_{e}=8-(2+2+2)=2$

Step 7 Mean square (variance):

$V_{A}=\frac{S_{A}}{f_{A}}=\frac{3.795}{2}=1.90$ and so on.

Step $8 \quad \mathrm{~F}$ value

$F=\frac{\text { variance of parameter }}{\text { variance of error }}$

$F_{A}=\frac{V_{A}}{V_{e}}=\frac{1.90}{0.77}=2.468$

and so on.

Step 9 Pure sum of squares:

$$
\begin{aligned}
& S_{A}^{\prime}=S_{A}-\left(V_{e} x f_{A}\right) \\
& S_{A}^{\prime}=3.795-(0.77 \times 2)=2.255
\end{aligned}
$$

Step 10 Percentage contribution:

$P_{A}=\frac{S_{A}^{\prime}}{S_{T}}=\frac{2.255}{137.792}=0.016$

\subsection{Calculation of the expected performance and the confidence interval}

As shown in Table 5, the experiment corresponding to the optimum conditions (A1, B3 and C3) had already been performed during experimental studies. Therefore, there was no need to repeat the experiment. According to this result, it can be said that the calcium removal under optimum conditions is $79.49 \%$.

Expected performance (EP) is calculated using the average $\mathrm{S} / \mathrm{N}$ value in Table 5 and the optimum parameter values for A1, B3 and C3 in Table 6. The EP value was calculated as follows; $E P=33.5562+(34.5209-33.5562)+(33.9182-$
$33.5562)+(36.3877-33.5562)$

$E P=37.7144$

The omega transformation of this value was performed.

$0.377144=-\log [(1 / P)-1), \quad P=0.7244$

$\% \mathrm{EP}=72.44$

Observed optimum removal quantity for calcium was $79.49 \%$. The confidence interval $(\mathrm{Cl})$ was calculated to decide whether this value is meaningful or not. Eq. (4)

Table 9. Optimum working conditions and optimum removal quantities of calcium.

\begin{tabular}{lll}
\hline Parameters & Value & Level \\
\hline Reaction temperature $\left({ }^{\circ} \mathrm{C}\right)$ & 12 & 1 \\
Stirring speed (rpm) & 350 & 3 \\
Resin amount (wt.\%) & 50 & 3 \\
Observed optimum removal quantity for calcium (\%) & 79,49 & \\
Expected optimum removal quantity for calcium (\%) & 72.44 & \\
Confidence interval (confidence level $\alpha=99 \%)$ & $64.77-80.11$ \\
\hline
\end{tabular}


was used to calculate the confidence interval at $99 \%$ confidence level. Confidence interval $(\mathrm{Cl})$ was calculated as follows:

$F\left(1, n_{2}\right)=F(1,2)=98.50$

$V e=0.77$

$\mathrm{Ne}=9 /(1+6)=1.29$

$C I=72.44 \pm \sqrt{\frac{98.50 \times 0.77}{1.29}}=72.44 \pm 7.67$

The optimum working conditions, the observed and expected quantities of calcium removal and the confidence interval obtained for this process are given in Table 9.

As shown in Table 9, the observed removal amount under optimum conditions $(79.49 \%)$ is within the calculated confidence interval and the experimental results are within $\pm 1 \%$ error. This indicates the accuracy of the observed optimum removal quantity for calcium and it can be said that the interactive effects of the parameter are at negligible levels.

\section{Conclusions}

The following results were observed in this study;

1. In the first stage of this process, ulexite ore was dissolved in phosphoric acid. The final solution contains boric acid $\left(\mathrm{H}_{3} \mathrm{BO}_{3}\right)$, sodium dihydrogen phosphate $\left[\mathrm{NaH}_{2} \mathrm{PO}_{4}\right]$, and calcium dihydrogen phosphate $\left[\mathrm{Ca}\left(\mathrm{H}_{2} \mathrm{PO}_{4}\right)_{2}\right]$. Boric acid production with the conventional method has specific disadvantages. These are; difficulties encountered during disposal of gypsum formed as a by-product and corrosive effect of sulfuric acid used as a solvent. Therefore, with the addition of valuable by-products produced in the current process and also elimination of disadvantages of the traditional method, this process may help provide cheaper production of boric acid compared to the traditional method.

2. In the second stage of this process, the removal of calcium ions from the product solution was investigated. Calcium ions in the final solution were replaced by sodium ions using ion exchange resin. There were already sodium ions in the product solution. Thus, variety in the product solution was reduced and the purity of boric acid was increased. In this process, using ion exchange resin for the removal of calcium ions in product solution provides many important advantages. With the aim of purifying boric acid, some methods such as chemical precipitation and membrane filtration may be used for separation of by-products. However, membrane filtration has higher costs. Chemical precipitation adds potentially polluting material to the solution. Using ion exchange resin in this process resolves these disadvantages. Another advantage of this process is that the resin can be regenerated with salt solution and does not require any chemical treatment. Moreover, innovative and original research that contributes to the scientific literature was carried out by using an ion exchanger for this separation process.

3. In the third stage of this process, the optimization of calcium removal from the product solution was examined. The effective parameters on calcium removal from the product solution obtained by dissolution of ulexite ore in phosphate acid solutions using ion exchange resin are resin amount, reaction temperature and stirring speed, respectively. The most effective parameter on the ion exchange process is amount of resin. While stirring speed had nearly no effect, temperature had a slight effect on the process. The optimum conditions were found to be $12^{\circ} \mathrm{C}$ for reaction temperature, $350 \mathrm{rpm}$ for stirring speed and $50 \%$ wt. for the amount of resin. The amount of calcium removal under optimum conditions was found to be $79.49 \%$. It can be seen that the Taguchi method is a suitable alternative experimental design method for use in a separation process because it is cheaper than other conventional design methods. In addition, the results obtained during the experimental work may be obtained in a factory environment using the Taguchi method.

\section{References}

[1] İçelli O., Erzeneoğlu S., Boncukcuoğlu R., Measurement of X-ray transmission factors of some boron compounds, Radiat. Meas. 37, 613-616, 2003.

[2] Künkül A., Yapici S., Kocakerim M. M., Copur M., Dissolution kinetics of ulexite in ammonia solutions saturated with $\mathrm{CO}_{2}$, Hydrometallurgy, 44, 135-145, 1997.

[3] Tombal T. D., Özkan Ş. G., Ünver İ. K., Osmanlıŏlu A. E., Bor bileşiklerinin özellikleri, üretimi, kullanımı ve nükleer reactor teknolojisinde önem, BORON 1 (2), 86-95, 2016.

[4] Budak A., Gönen M., Extraction of boric acid from colemanite mineral by supercritical carbon dioxide, J. Supercrit. Fluids, 92, 183-189, 2014.

[5] Karagöz Ö., Kuşlu S., Dissolution kinetics of colemanite in potassium dihydrogen phosphate solution $\left(\mathrm{KH}_{2} \mathrm{PO}_{4}\right)$, Int. J. Hydrogen Energy, 42, 23250-23259, 2017.

[6] Çelikoyan B., Bulutcu AN., Kolemanitten yeni bir yöntemle borik asit üretim prosesinin geliştirilmesi, ITU Dergisi/D Mühendislik, 9, 15-26, 2010.

[7] Imamutdinova V. M., Rates of dissolution of native borates in $\mathrm{H}_{3} \mathrm{PO}_{4}$ solutions, J. Appl. Chem. USSR, 40, 2596-2598, 1967.

[8] Temur H., Yartaşı A., Çopur M., Kocakerim M. M., The kinetics of dissolution of colemanite in $\mathrm{H}_{3} \mathrm{PO}_{4}$ solutions, Ind. Eng. Chem. Res., 39, 4114-4119, 2000.

[9] Küçük Ö., Kocakerim M. M., Yartaşı A., Çopur M., Dissolution of kestelek's colemanite containing clay minerals in water saturated with sulphur dioxide, Ind. Eng. Chem. Res., 41, 2853-2857, 2002.

[10] Doğan H. T., Yartaşı A., Kinetic investigation of reac- 
tion between ulexite ore and phosphoric acid, Hydrometallurgy, 96, 294-299, 2009.

[11] Kizilca M., Copur M., Kinetic investigation of reaction between colemanite ore and methanol, Chem. Eng. Commun., 202, 1528-1534, 2015.

[12] Küçük Ö., Application of Taguchi method in the optimization of dissolution of ulexite in $\mathrm{NH}_{4} \mathrm{Cl}$ solutions, Korean J. Chem. Eng., 23, 21-27, 2006.

[13] Ekinci Z., Şayan E., Beşe A. V., Ata O. N., Optimization and modeling of boric acid extraction from colemanite in water saturated with carbon dioxide and sulphur dioxide gases, Int. J. Miner. Process., 82, 187-194, 2007.

[14] Doğan T. H., Yartaşı A., Optimization of dissolution of ulexite in phosphate acid solutions, J.Chem.Soc.Pak., 36, 601-605, 2014.
[15] Taguchi G., Introduction to quality engineering, New York: Mc Graw-Hill, 1990.

[16] Çopur M., An optimization study of dissolution of $\mathrm{Zn}$ and $\mathrm{Cu}$ in $\mathrm{ZnS}$ concentrate with $\mathrm{HNO}_{3}$ solutions, Chem. Biochem. Eng., 15, 191-197, 2002.

[17] Scott W. W., Standard Methods of Chemical Analysis, Van Nostrand: New York, 1963.

[18] Phadke M.S., Quality engineering using robust design, Prentice Hall: New Jersey, 61-292, 1989.

[19] Roy R. K., A Primer on the Taguchi Method; Competitive Manufacturing Series, 1990.

[20] Wu Y., Wu A., Taguchi methods for robust design, The Park Avenue, New York: The American Society of Mechanical Engineers, 2000. 